\title{
"The mouth that ate itself": Reflections on Joseph Kamarũ, oral artist extraordinaire Gĩchingiri Ndĩgĩrígĩ
}

\section{Introduction}

After a liberating sojourn in a pastoral Ilmorog, Munira, the central character in Ngũgĩ wa Thiong'o's Petals of Blood returns to his home in Limuru, only to be demeaned by his rich father. During a compensatory bar-hopping night out on the town, he runs into Karega, an old acquaintance who has fallen on hard times. The narrator evokes the pathos in the moment thus:

I saw him. He was gesticulating with an empty bottle of Tusker in his hand. His drunken voice rose above the others. They were arguing about the merits of [Joseph] Kamaru and D. K. [Daniel Kamau]. He was shouting Kamaru sings about our past: he looks to our past, he wants to awaken us to the wisdom of our forefathers. What good is that to the chaos that is today? Another was arguing: his is the tinkling of a broken cymbal. But D. K. sings true-about us-the younghere and now - a generation lost in urban chaos. Another interrupted: we are not a lost generation [...] Don't you go about abusing folk in a bar doing their thing. Gee-I gonna dance to Jim Reeves and Jim Brown and break a safe or two like some cowboys I saw in the Wild Bunch-Gee. (101)

The latter speaker is noteworthy for the slangy American words he uses to amplify his affectation, and the choice of American country and soul music preferences as opposed to the local Kenyan musicians who excite Karega and his first interlocutor. In this paper I focus on Kamarũ’s music for three reasons. First, the archiving of our past that Karega celebrates in Kamarũ's music ran parallel to efforts by many of the first generation of East African writers, including Ngũgĩ, to answer Achebe's challenge to African writers to show that their pasts had beauty, dignity, and a philosophy of great depth ("The Role of the Writer in a New Nation" 8). Second, the recognition of oral literature in East African academic settings since the 1960s foregrounds the role of the oral artist not only in preserving a seemingly fossilized past, but also responding more immediately to a changing environment like the D. K. in the second interlocutor's comment. Above all else, Kamarũ was an oral artist of exceptional skill. He is also the same artist who challenged Kanda Bongoman, the Paris-based Congolese king of kwasa kwasa, to a performance contest at City Stadium in 1990 and soon incorporated a more frenetic dance climax in his songs after the encounter, attesting to his adaptability to changing tastes. Reviewed in its entirety, Kamarũs music reveals how he also responded to a generation lost in urban chaos in a way that creates an intertextual synergy between music and creative literature, and extends the meaning-making abilities of the literary text. Third, if East African creative writers retreated to safe havens during the reign of dictators in the 1970s and 80s, Kamarũ appears to have filled the gap by composing and disseminating searing critiques of despotism couched in several creative oral performance tropes that I explore shortly. His songs fill some of the gaps in the creative literature.

There is a certain irony that almost immediately after making the comment celebrating Kamarũ's cultural retrieval, the drunken Karega - who is at that point a sad example of the lost youth of the second interlocutor's comment - falls asleep as a song by D. K. about a young man who has failed the responsibility of taking care of his aging mother-like Karega himself-plays on the jukebox. He will eventually realize by the end of the novel that cultural awakening by itself is inconsequential if the material expropriation that accompanied the cultural loss is not addressed. After a lengthy flirtation with Afrocentrism, Karega undergoes a Fanonist turn and recognizes the folly of his earlier investment in glorious pasts: "all this knowledge [of such pasts in India, Syria, Iraq, Palestine] never once deterred the European merchant warlords. And China was saved, not by singers and poets telling

Gĩchingiri Ndĩgirĩ̃̃̃ is a professor of English at the University of Tennessee, Knoxville, United States, where he teaches African and Caribbean literatures. An interdisciplinary interest in literary criticism, folklore and mythology, and performance informs his research and publications.

Email:jndigiri@utk.edu

(D) https://orcid.org/0000-0001-5478-9973

D0l: https://doi.org/10.17159/tl.v58il.10413 
of great past cultures, but by the creative struggle of the workers for a better day today" (Petals of Blood 301). As Fanon stated,

The native intellectual nevertheless sooner or later will realize that you do not show proof of your nation from its culture but that you substantiate its existence in the fight which the people wage against the forces of occupation. No colonial system draws its justification from the fact that the territories it dominates are culturally non-existent. You will never make colonialism blush for shame by spreading out our little known cultural treasures under its eyes. (223)

The same fight against the forces of occupation that we see in the retrospective narratives about Kenya's war of liberation find their equivalents in Kamarũ's songs, particularly his two-volume cassette collection titled Mau Mau Patriotic Songs. If the creative artist retreated from confronting the East African dictator, the internal force of occupation in the 1970s and 80s, or donned the cloak of comedy in order to continue "telling the truth laughingly" as John Ruganda said of Francis Imbuga's drama, both Ngũgĩ and Kamarũ expressed almost the same level of outrage after the populist J. M. Kariũki's murder in 1975 through fiction, essays, and song. In addition, Ngũgîs theatrical satires of the period derived from and subsequently informed popular music. Ngaahika Ndeenda (I Will Marry When I Want) derived its title and one of its most relatable songs from D. K.'s song titled "Ngarua Ndeenda". After Kamarũ watched the theatrical performance at Kamĩrĩthũ in 1977, he composed a song titled "Kĩuru" in which a Kioi-like character with a history of complicity with the colonizers becomes an exploitative large landowner after independence. If the questing Gatuĩria of Ngũgîs Devil on the Cross searches for the voices and local instruments that will fill his oratorio on Kenyan history, the Ngũgĩ who vicariously searched for such an oratorio and ended up gathering his collections in Maitu Njugira travelled the same path that Kamarũ trod in life and archived through music. The anglophilic cabinet minister and the neocolonial ruling elite satirized in Matigari are the same ones being reminded that political leadership derives its legitimacy from the people in Kamarũ’s "Kenya ya Ngai". While Ngũgĩ and other creative writers critiqued the Moi state from the safety of exile, Kamarũ found a way to say the unsayable from within the Kenyan territorial space by mobilizing double-voiced Gĩkũyũ cultural treasures in praise of the ruling elites.

If the study of oral literature/folklore and mythology avails a rich cultural intertext that extends the meaning-making abilities of East African literary texts, might an investment in a dialogic study of creative and expressive arts be equally rewarding? If we refuse to be persuaded that literary criticism is such a fragile and insular discipline that it should not be contaminated by approaches steeped in interdisciplinarity or historicism or even high theory, we might find that literary studies may gain if we see literature as a "particular cultural practice related to other discourses [...] one signifying practice among others $[\ldots]$ in a complex intertextual phenomenon", as Jonathan Culler suggests (46-7). I offer a sample study of Kamarũ’s songs as an example of the way other arts illuminate the complex issues in late twentieth century Kenya.

\section{Kamarũ's archive}

When Joseph Kamarũ passed away in 2018, it was like the closing down of the doors to a living cultural archive. Though he sang mostly in Gĩkũyũ, Kamarũ was easily one of the most prominent Kenyan musicians from the 1960s into the 90s. The language of composition reminds us of some of the limitations of creative production in ethnic languages that faced musicians and creative writers alike. As Achebe remarked regarding his meeting with Shabaan Robert in 1960, he was aware that he was "in the presence of a great writer, but of the nature of his writing I had no idea" because he could not read Swahili ("The African Writer and the English Language" 431). Music may provoke a different affective response, but the beauty of Kamarũs music derives from his masterful song writing that deploys powerful imagery, lexical economy and dexterity, and deep symbolism and metaphoric discourse that require an almost encyclopedic intertextual knowledge of the intricacies of Gĩkũyũ culture and language. That he was able to thread his narrative songs with this richness might tell us that we had a poet and storyteller whose skill is yet to be discovered.

With over 1000 compositions to his credit, Kamarũ was a master of many song genres ranging from generic love songs, ballads, blues, waltz (the Gĩkũyũ mwomboko 'borrows' its dance step and the accordion from Scottish waltz), and country - admittedly inspired by "Jimmi Rodger", elegy, wedding songs, circumcision songs, political songs, and gospel. If the earliest generation of modern African writers felt called upon to be the sensitive needles, the moral barometers of their communities à la Achebe, Mphahlele, etc. (Achebe, "The Novelist as a Teacher" 45), they were carrying into print a function and practice that had been the preserve of oral artists from the village sto- 
ryteller to the more professional performers of epics. Like the traditional oral artist who preserved the communal lore and presented himself as a communal voice whose autonomous art could not be compromised, Kamarũ left a lasting legacy as the conscience of the nation and that will be my focus for the rest of this paper, in which musical political commentary is central. In what follows, I locate Kamarũ's critique within his larger oeuvre that is far too large to review. Following a suggestive free translation of his most remarkable individual songs, that locates them within their contexts, my focus shifts to the two significant phases of his political music making.

Kamarũ wrote generic love songs like "Nũũ Ũcio?" (Who was that?) and "Reke Nyambe Ngwĩitînĩrie" (You are Free [to go]) about love triangles. He also composed ballads like "Gathoni", the slender girl with a gap in the teeth and hair like that of a Boran woman, and "Tũgatigithanio nĩ Gĩkuũ" (Only Death will Separate Us) about two lovers from Nyeri and Kangema who refuse to let the fighting during the 1950s State of Emergency and the exceedingly cold season in August keep them from having a wedding, and stage such a magnificent one that it results in the birds chirruping a complaint that they had not been invited to the wedding feast. Others like "Wendo wa Chebe Chebe", the blues song about inconstant/toxic love that was akin to living in a perpetual remand cell, became paradoxically popular in dance halls of yesteryear. Kamarũ’s mobilization of affect and embodied expressions lent force to lyrics that were masterfully crafted, observing proper rhythm and meter, and melodic lines that do not just drop off the edge of a page or beat. One could also point to the elegy to J. M. Kariũki and the melancholic Mau Mau Patriotic Songs as lasting popular records of major moments in Kenyan history. In addition, the popular pre-pandemic Mũgithi may have had its roots in such Kamarũ songs as the wedding evening party favorite, "Nĩnyuo Ndĩrĩ Nyagachũ" (Let us Toast the Newly-weds) that evoked a traditional beer (mũratina) toast celebrated in an escort dance-train formation that eventually became the centerpiece of Mũgithi nights. In the song, the joy surrounding the festivity is such that even the despised co-wife and her brood (nyagachũ) cannot be denied a chance to join the toast. If ribaldry became the centerpiece of Mũgithi performance, it had its more innuendo-laden forerunners in Kamarũ's "Irua" (Circumcision [Song]), and "Kĩndũ kĩa Maunaî" (a song that would be liberally translated by sing-along drunks as "Mũnaîs privates" by a devious phonemic pun on "kĩndũ/thing"). The reception of the song paved the way for a full-length cassette titled Kikuyu Folk Songs: Adults Only, in which Kamarũ unleashed the seasonal license for ribaldry during the traditional Gĩkũyũ circumcision season onto the Kenyan nightclub scene of the mid-1980s. It remains a collector's item for multiple song genres like mũthũngũci, mũthuũ, mwomboko, mũmbũro, and nduumo. At a time when folklore and folksong collection and preservation was only just beginning in earnest, Kamarũ had already collected or composed a whole library that also includes two classics titled "Mĩtugo ya Gĩkũyũ" (Customs of the Gĩkũyũ) and "Mĩtĩ ya Gĩkũyũ" about Gikũyũ traditional trees and their functions.

Kamaru's encyclopedic "Mĩtugo ya Gĩkũyũ" and "Mĩtĩ ya Gĩkũyũu appear to be the culmination of an effort to preserve fast-disappearing traditions. Like the traditional oral artist who preserved the communal lore but also recognized the emerging cultural changes, Kamarũ started singing songs critical of the rapid modernization in the 1960s. He also presented himself as a communal voice whose autonomous art could not be compromised, even as he spoke as the conscience of the nation, unafraid to address hot-button issues through song. On the preservation aspects, one recalls such songs as "Ndanuko cia Mĩtahato", an evocation of the loving care with which rural mothers would orally mash bananas (mĩtahato) in their mouths for feeding new-borns who could not handle solid food. When the same children were all grown up and living in the city, they looked down upon the simple lives their parents still led and refused to visit them. Parents of "modern" girls who forget the beauty and dignity of traditional marriage rituals and devalue bridewealth into an exploitative commercial transaction are reminded about them by Kamarũ speaking as an emissary of tradition-bound young men in "Ndũmĩrĩi cia Mĩhũũni". In "Kĩbaata kĩa Matukũ Maya" (Modern Dance) Kamarũ laments the corruption of the age and gender-defined customs that regimented which group got to dance to which dance, and which pairing was taboo. The dance space (Kïbaata) in the modern dispensation is the bar, where old men and young women, fathers and daughters, sons and mothers partake of modern drinks that remove all inhibitions, and dance the "twist" and rumba with predictable results. ${ }^{2}$ The earliest noteworthy social critique that would earn Kamarũ notoriety was a mid-1960s song titled "Ndari ya Mwarimũ" (The Teacher's Darling Student) in which he critiqued the then pervasive predatory love affairs between male teachers and their female students. It was probably the first song to be denied airplay on KBC Radio, the national broadcaster, at the instigation of the national teachers' union. To his credit, Jomo Kenyatta reversed the ban, telling teachers to sue Kamarũ in a court of law if they felt that aggrieved. Way before the awareness about the dangers posed by dead-beat dads and date/acquaintance rape gained currency, Kamarũ released two songs in the 1960 s about advantage-taking males. Deploying a female subject's words, "Na Ugatorooka" (You Dared Escape 
[responsibility]) critiqued an urbanized man who misled an innocent rural girl with endearing words, but then escaped from his Nairobi base to Tanzania once he learnt that the pregnant girl was looking for him in the city. Implicit in this critique is the recognition that the traditional sanctions and fines that would have been imposed on such a man were no longer operative. "Tiga Kũhenia Igooti" (Stop Lying to the Court) lampoons men who take advantage of female friends and needy rural girls and defile them without accepting responsibility for the trauma by claiming that the intimacy was consensual when they face prosecution. Beyond romantic entanglements, Kamarũ flagged the emerging class-based injustice through such songs as "Kĩhooto Kĩigwo Mwanya" in which the refrain is that the poor deserve equal justice with the rich. When Idi Amin threatened to annex Kenyan territorial space in the late 1970s, Kamarũ warned him not to dare in "Nĩ Maitho Tunĩte" (Only Our Eyes are Averted). The attempted military coup in 1982 was memorialized in "Baraka za Kenya" (Kenya's Blessings), one of the few songs Kamarũ composed in Swahili to remind Kenyans of the ties that bind their imagined community.

If the political class celebrated when Kamarũ sang in praise of Kenyatta as the ageing rooster that had not lost its vitality in the metonymic national homestead in "Aromaka" (Confound him), a decidedly anti-Odinga song of the late 1960s, he was the same artist who would later sing the caustic elegy "J. M. Kariuki Mwendwo Nĩ-irî" in which he called for those responsible for J. M's murder to be ritually stuffed into beehives and rolled down a hillside to their deaths, the traditional Gĩkũyũ punishment for miscreants. ${ }^{3}$ The Kamarũ who sang "Safari ya Japan"—a praise song for Moi, Kenya's second president, for including average Kenyans like Kamarũ in his entourage to Japan — would also unleash "Kenya ya Ngai", "Chunga Marima", "Waica Kehiri”, etc. before abandoning the allusive and allegorical mode for the more trenchant political critiques in his 'message' sermon cassettes of the 1990s. Kamarũ left a lasting legacy at the level of musical political commentary and that will be the focus of the rest of this essay. Some context is in order.

I interviewed Kamarũ twice (1989 and 1993) in circumstances that illuminate his political courage. In 1989, the editor-in-chief of the soon-to-be defunct Financial Review asked me to do a profile on Kamarũ. When I met him at his River Road studios, I fully disclosed that it was Peter Kareithi who wanted to do a profile on him, at a time when the weekly magazine was a thorn in the flesh of the Moi state. It was closed down within months of the interview and the profile was never published. In 1993, Ngũgĩ wa Thiong'o was planning to launch Mũtiiri, the Gĩkũyũ language journal through which he hoped to show that African languages are adequate vehicles for creative expression and critical thought. I was preparing to do my initial dissertation research on Kamĩriithũ when I contacted Ngũgĩ for some context on his role in the theater project. He expressed interest in a critical article on Kamarũ̃s music, if it was in Gĩkũyũ. I made an appointment with Kamarũ and fully disclosed that it was the "dreaded" Ngũgĩ who wanted an article on him. He did not even flinch. However, the Kamarũ I interviewed in 1993 was different from the one I had interviewed in 1989.

\section{Saying the unsayable}

In 1989, Kamarũ still had faith that his richly allusive music could prick the political class into doing the right thing for the people who had elected them. His critique was broadly directed at the spineless politicians who supplicated themselves to foreign interests and the ones beholden to local tin gods. However, the message is couched in proverbial discourse directed at the initiated. In "Kenya ya Ngai" (Kenya, God's [Gift]), for example, the 1983 "traitor" controversy is woven into a timeless message. ${ }^{4}$ The singer wonders whether the Kenya that was being auctioned to foreign interests is the same Kenya for which blood was shed in the liberation struggle, promising that if it owes any debts, he is ready to pay them, just as they paid for independence with much blood. Using war imagery, the singer warns that the nameless threat could not escape entrapment, and then switches to the language of commerce. The threat is an elected politician for whom people voted so that he would advance their interests. Instead, he has "wrapped Kenya in banana leaves" like tobacco bound for the village market, but the singer wonders where the politician will be able to sell it without God, its guardian, noticing. Further, those intent on auctioning the country are warned that it is not a marriageable woman on whose behalf they could request the traditional beer that initiated negotiations over bride wealth. If anybody had partaken of such a ritual drink, he had to be ritually purged before the singer pronounced the curse words that would make the beer harm the opportunist who consumed it outside ritual sanction. As the singer concludes, Kenya may have had a sore throat, but prayer might fix it, obviating the need to mortgage the soul of the nation and its people. He also includes a rider that all power is God-given, which makes the curious listener wonder whether even the power the president himself was deploying recognized the source of its legitimating moral authority. Richly allusive lan- 
guage, no names mentioned, but the message resonated in the topical moment while also speaking to all patriots who are called to reject those who would rock the nation "like wind in a napier grass patch that has no owner".

In "Chunga Marima" (Watch the Holes) the singer amplifies the oblique messaging regarding political opportunism. Singing that those who throw missiles meant for their enemies have no control over who escapes them and who does not, the singer warns an unnamed person to watch the holes in the figurative homestead. The message relies on an understanding of traditional Gĩkũyũ homesteads and the wise sayings that concretized the idea of fate. The shared courtyard space between the man's hut and his wife's or wives' had to be kept clean and free of obstacles, holes, or wetness. The communal lore held that there is no escaping a hole in the nja (the courtyard) or to avoid falling in that space if the ground was slippery. As the space that was crossed and crisscrossed repeatedly by almost all people in the homestead, if they were going to trip anywhere it would most likely happen there. The domestic space is used as a metonym and a metaphor of regional and national political space. Characteristically, the singer reveals that he will be speaking in code: he will not rip open the message he is carrying, he will "cut" it like sugarcane. The un-initiated will go for the younger top part of the cane, leaving the sweeter parts for others. He does so because danger still lurks around: women's skirts cannot be compared to the feathers on a hen; what is given to the hen may not be enough for the rooster; one who crosses a river at a cursed watering point has to be careful; watch the holes; let us find a remedy for moles before they consume all our yams; let us hunt the traitor down before he escapes. On and on the singer goes before concluding: what is this disease that afflicts us, yet we know that it is not yaws? Can we find a good traditional healer to excise it before it spreads, now that the thorn used to pierce it and pus "never get a good night's sleep"?

Every animal has a shelter, I am going home

but let me say that I come from Kangema, my cousin from Nyeri

If anybody needs me, he will find me there

but let him come in peace,

the singer says, before ushering in the final refrain:

Watch the holes; if you trip, you should not say that I did not warn you. (my translation)

The warning not to take war to the singer arises out of a common understanding that if one does not like the message, they should not fight the messenger. Could this message have been directed only to Mwai Kibaki, the "cousin from Nyeri", to watch his back and the holes in his regional homestead and the traitors who may have dug them, or the moles that may have been eating his yams, or the enemies who were throwing missiles, not knowing who might be able to evade them? The video compact disc version of the song flashes images of Kibaki giving speeches in several places, but was there a regional political kingpin from Kisumu to Mombasa who could sleep peacefully during the paranoid 1980s and 1990s Nyayo era in which opportunism and political sycophancy had been perfected into a performance art? $?^{5}$ I could amplify this reading by parsing "Waica Kehiri" in which the singer lambasts the opportunists who had sold their souls for a derisive "runyeni", a metonymic single leaf of a previously wild vegetable that was domesticated by the Gĩkũyũ, even though there was no famine in the country, but that might be belaboring the point. However, it is worth noting that the seemingly masterful puppeteer's antics are not being celebrated. In the end, the singer's frustration as captured in the songs about this period was that politicians were pursuing power for their own ends-the electorate, ethics, and morals be damned! This frustration explains Kamarũs turn to the sermon-like "message" mode of the 1990s, delivered as a talk given against the background of a flat drumbeat.

In an extended interview with Kamarũ in July 1993 that I tape-recorded openly, I probed him on the role he played in the fluid political environment in Kenya in the run-up to the reintroduction of multi-party democracy in 1992. I was particularly curious about the fact that despite releasing a fairly caustic cassette titled Mahoya ma Bũrũri (Prayers for the Nation) in the run-up to the Saba-Saba rally on 7 July 1990, he appeared not to have paid a heavy personal price. There were also no reports that copies of the cassette were mopped up by the coercive state apparatus like the equally critical Thina wa Muoroto (Precarity in Muoroto) released around the same time by John Mugo Muoni. His honest discussion of the intrigues that kept him out of jail or detention, or being 'disappeared', speaks to his ability to use his music to speak truth to power by mobilizing double-voiced utterances. If irony functions through a wink to those in the know, Kamarũ's mobilization of three oral performance tropes, the self-description as "kanya ka unhoro" (the gourd/container-really the bearer-of news), "mwaria njarie" (he who 
only amplifies what is being discussed in whispers), and "kanua weriire" (the mouth that ate itself) invites some probing. He used variations of the three tropes in his critiques of the Kenyatta and Moi states in songs like "J. M. Kariuki Mwendwo Nĩ-irî”, "Musa wa Andu Airũ”, "Atongoria Nĩ Inyuĩ Itugî”, "Chunga Marima”, "Kenya ya Ngai", "Waica Kehiri", etc.

\section{The mouth that ate itself}

In the days leading up to the 7 July protest meeting slated for Kamukunji Grounds, several leading Kenyans who were championing political change were rounded up and either placed under house arrest, or in formal custody or detention without trial. Kamarũs band members were locked up at Central Police Station and when he went there to find out why they had been arrested, he, too, was arrested on 6 July 1990, but apparently, Moi wanted to interrogate him personally at State House. Kamarũ was delivered to the then president and given the opportunity to explain his "subversive" message in Mahoya ma Bũrũri. Kamarũ explained to the president that political opportunists had been feeding him with a misinterpretation of Kamarũ's message, which was in Gĩkũyũ, a language the president did not speak. The bone of contention appears to have been the literal reading of the lines to the effect that Moi was going to "gũikio irima ta Danieli" (literarily be thrown into a hole/den like Daniel) which his informers suggested was code for the idea that the unpopular president would be killed and buried. Kamarũ apparently clarified that by invoking the figure of the biblical Daniel in his message, he had actually been signaling to the president that he would be tested during the period like the analogously named Daniel who was thrown in a den of lions that did not consume him because God was on his side. Kamarũ explained that, as a friend of the president, he had actually been praying for Moi. His explanation apparently moved Moi to tears and he immediately asked Kamarũ to translate the message in the cassette into Swahili so that more people would hear the message. Kamarũ went ahead to translate the message, but when he attempted to deliver the tapes to State House later, he found his access blocked. Apparently, the same opportunists had succeeded in convincing the indecisive president that their own interpretation of Kamarũ's message was the authoritative one. Kamarũ played samples of the translated message for me during the interview, and what struck me was his ability to weave a message that was open to interpretation depending on the interpreter's interests, even though he had moved away from the more richly metaphorical language of the 1970s and 80s.

Following Mikhail Bakhtin, it is now accepted that any utterance is dialogic, and a speaker does not have a monopoly on meaning. As Bakhtin argues, "[...] language is not a neutral medium that passes freely and easily into the private property of the speaker's intentions; it is populated —overpopulated —with the intentions of others" (294). To what extent, then, was Kamarũ a neutral conveyor of messages that were not overpopulated with his own intentions, even as he blamed his accusers of overpopulating his message with their own intentions? In his translated message, he consistently reverts to the Gĩkũyũ mode of call-and-response performance in which he frames himself merely as a soloist calling on his chorus to respond to the message from "mwaria njarie" (he who only repeats what was already being discussed, ostensibly in whispers). He repeatedly wondered why he, "kanua weriire" (literarily the mouth that ate itself, but meaning the mouth that talked too much), was being persecuted. Understanding the contradictoriness of the two tropes illuminates how Kamarũ created a slippery slope on which any interpreter was bound to slip. Can one really say only what is already being discussed, perhaps saying the unsayable, yet be "the mouth that ate itself", saying more than the rational mind would find safe? Was Kamarũ only a neutral conveyor of messages-"kanya ka ũhoro"-as he also repeatedly labeled himself?

It is important to briefly delve into Gĩkũyũ gnosis to understand Kamarũ further. Popular wisdom held that those who are enlightened about pertinent matters do not require messages containing overt texts (ciunagwo rũkomo, kĩmenyi akamenya ikiunwo, mũũgĩ ndarĩ mũheere wa ũhoro, etc.), but they also held that "ndithũire mũnyoni ta mũnyanĩriri" (I do not hate the one who sees my faults; I hate the one who broadcasts them), or its variationndĩthũire mũmĩoni ta mũmĩanĩriri (an antelope does not mind the one who sees it, it hates the one who mobilizes the hunters). In the interview, Kamarũ consistently lamented that people had refused to listen to his nuanced political critiques in the political songs mentioned earlier, forcing his turn to the 'message' cassettes like Mahoya ma Bũrũri, Message to the Youth, and Kunroga, a call to curse and banish contaminants. Listening to the translated Mahoya in his River Road office, I could not help noticing that at one point he compared himself to Moses, he who led the Israelites across the desert and at some point, reportedly threw down the tablet with the Ten Commandments in 
frustration. Upon further review of my interview tape (Gĩchingiri and Kamarũ), I find these words in the refrain really striking:

\author{
Fuata nyayo za Mwenyezi Mungu \\ Kenya yangu, nakupenda mama yangu, sitakuacha \\ Kenya yangu, baba yangu, sitakuacha \\ Follow God's footsteps \\ My Kenya, I love you my mother[land], I will never abandon you \\ My Kenya, my father[land], I will never abandon you
}

In the message Kamarũ devolved leadership to all parents who had teenage children whose morals they were called to guide to save the country that he found messed up. He also voiced his frustration that people were lying to Moi that they were following in his footsteps. If this was the same "prayer" that Kamarũ summarized for Moi, it is no wonder that he might have become the mouth that ate itself by over-explaining his otherwise coded messages. But, more fundamentally, Kamarũ had punctured the president's cloak as the benevolent father of the nation who presided over the ruling party that was celebrated as "baba na mama" (father and mother) of infantilized Kenyans. However, if Moi expected the people to uphold a God-given moral code and act in His image, could they conceivably follow God's "nyayo" (footsteps) at the same time that they were expected to follow the mortal Moi's slogan of "fuata nyayo" (follow [my] footsteps)? If Kamarũ's call to the people was to recognize themselves as the glue that held the nation together while the leaders were only pillars in an echo of an earlier song from the late 1970s ("Atongoria nĩ ĩnyuĩ ĩtugî"), or if all parents were really the leaders, how was this call for the recognition of their popular sovereignty to be reconciled with Moi's investment in the image of the all-powerful sovereign? If he saw the agitation for pluralism as the equivalent of the Gîkũyũ "ituîka", or generational succession from one ruling group to the next, was he just a neutral messenger-the message-carrying gourd-or "kanua weriire", the mouth that got its owner into trouble by explaining more than the rational head wanted? Was it any wonder that some political opportunists that will remain nameless were able to flatten Kamarũs message into one meaning consumable by a president who saw himself as having a monopoly over the construction of national meaning and its interpretation? If the earlier musical political commentary was too figurative and allusive to get through to listeners, were the message tapes too overt in meaning? Was it any wonder, then, that Kamarũ was blocked from seeing Moi to deliver the translated Mahoya tape? Had the president been toying with him all along as Kamarũ speculated during our interview? There was one more complication to this narrative.

In the run-up to the first multi-party elections in December 1992, Moi dispatched emissaries to Kamarũ inviting him to support the ruling party, KANU, publicly. He even invited Kamarũ to perform at the national celebration of Kenyatta Day on 20 October. Kamarũ accepted the invitation, but he used his televised address to tell Moi to his face that the people did not want him. Kamarũ would only comment euphemistically that he was subjected to "heat" for his comment. According to him, he was only telling Moi what his sycophants could not, or would not. Very tellingly, Kamarũ was not arrested, jailed, detained, or "disappeared". Could it be that his mask, "mwaria njarie" (the one who speaks aloud what others can only whisper) protected him after all? But even as he deployed this mask, he had to be aware of the contrarian Gĩkũyũ saying "ndithũire mũnyoni ta mũnyanĩriri" (I do not hate the one who sees my faults, I hate the one who broadcasts them), a saying that he mobilized in "J. M. Kariuki Mwendwo Ni-iri", the song that critiqued Kenyatta's regime after its reported involvement in Kariuki's murder in 1975. By dancing around in slippery masks signifying that he was only a messenger, a loose tongue, and only a parrot, Kamarũ was consistently able to say the unsayable and stay out of jail, detention, and avoid being "disappeared" or bought and paid for. It is a testament to his skill with words that, having said the unsayable, or gotten his mouth to "eat" itself, Kamarũ could point to politicians and lament that they had overpopulated his messages with their own intentions, thus refocusing attention on the dialogic message itself.

\title{
Conclusion
}

In closing, I loop back to the suggestions in the introductory section, particularly Culler's idea that literature is only one signifying practice among others in a "complex intertextual phenomenon" that valorizes interdisciplinary approaches to literature. Kamarũ captured the burning issues of the day in song, and his collection is useful in illuminating the context for studying the alternatives to self-censorship in the literature of the period. Having 
teased out the possible synergies between Kamarũ's music and Ngũgî’s writing as an example, and recognizing the place of traditional songs and popular music more generally in Ngũgĩs writing, I close with three suggestive questions. First, how many other traditional or popular artists' work might be useful companion pieces to the study of creative works from the period? Two, if his language of composition limited Kamarũs audience, is it possible to effectuate Ngũgĩs suggestion that translation might bridge the gulf between languages, so that one day there might be a collection of Kamarũ's translated songs, from the traditional — with a guide for the dance choreography - to the romantic and the political? Achebe's hope that his people would one day recognize that there was nothing shameful in their weather, that the palm tree is a fit subject for poetry, invites some more context for the third question. Kamarũ’s evocation of the universal sublime in "Tũgatigithanio nĩ Gĩkuũ", for example, mobilizes a "fresh" appeal to sensory experience, fear, joy, and wonder. The couple journeys through a war zone in the bitterly-cold August - when birds freeze to death in their nests—and partake in the preparation for the feast for which "the grinding stone was having a conversation with millet near the granary, and the birds were chirruping complaints that only they had not been invited to the feast". The people celebrate the bridegroom's courage by mythogizing him as a giant who could throw a machete nine miles away. So here is the third question: following musician Bob Dylan's recent award of the Nobel Prize for Literature in recognition for the artistry in his songs, would incorporating Kamarũ's songs and those of the countless artists who sang a version of Gidi Gidi Maji Maji's "Unbwogable" in intertextual/interdisciplinary conversations about our age be too high a prize/price? Kamarũ’s songs reward a more sustained close textual analysis than the one undertaken in this exploratory discussion. ${ }^{6}$

\section{Notes}

1. A former political detainee during Kenya's liberation struggle of the 1950s, Kariũki became a threat to the Kenyatta state in the early 1970s for his popular nationalism and critique of the emerging inequities in the independent state. He was brutally murdered in March 1975.

2. One may recall the scene in Ngũgĩ’s Petals of Blood referenced earlier, in which the bar patrons ironically dance to the song about abandoned rural parents and resume "their hip-gyrations, all facing the juke-box, almost as if they were fornicating with a woman hidden in the music box". Just before recognizing the drunken Karega, Munira had just had a fantasy about making love to Wanja in public on the floor of the bar (101).

3. A doyen of the anti-colonial struggle especially in the legislative arena, Oginga Odinga was Kenya's first vice president up to 1966 when he left the government to form the official opposition party KPU after falling out with Kenyatta over the independent state's policies.

4. A then-powerful cabinet minister was rumored to have procured foreign help to help him seize the reins of state power from the serving president whom he had helped acquire power in 1978 specifically because the minister thought Moi would be a pushover. A well-cultivated campaign was mounted all over the country forcing the Anglophilic minister to step down.

5. Almost all of Kamarũ's music is available on YouTube or on the website www.josephkamaru.com. Kibaki was Moi's vice President between 1978-88. Almost immediately after the fall of the Anglophilic cabinet minister who had been angling to cut Kibaki down to size, Kibaki was himself subjected to Machiavellian palace intrigues hat progressively undermined his influence around the country, and even in his regional Nyeri base.

6. A scholarly collection of essays on East African music that would be of interest in advancing the kind of conversations I am suggesting is Njogu and Mapeau's Songs and Politics in Eastern Africa (2007).

\section{Works Cited}

Achebe, Chinua. "The African Writer and the English Language." Colonial Discourse and Postcolonial Theory: A reader, edited by Patrick Williams \& Laura Chrisman. Columbia U P, 1994. 428-34.

"The Role of the Writer in a New Nation." African Writers on African Writing, edited by G. D. Killam. Heineman, 1975.

"The Novelist as a Teacher." Hopes and Impediments: Selected Essays. Anchor, 1988.

Bakhtin, Mikhail. The Dialogic Imagination. Trans. Caryl Emerson \& Michael Holquist. U of Texas P, 1981.

Culler, Jonathan. Literary Theory: A Very Short Introduction. Oxford U P, 2000.

Fanon, Frantz. The Wretched of the Earth. Trans. Constance Farrington. Grove Weidenfeld, 1963.

Kamarũ, Joseph. "Chunga Marima." Nduti One Stop. Nairobi, n. d. VCD.

Ndĩgĩuĩgĩ, Gĩchingiri \& Joseph Kamarũ. Interview. Nairobi, Jul. 1993.

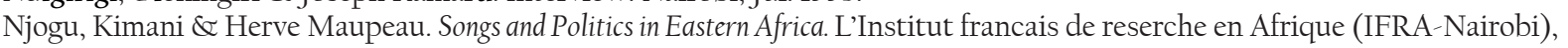
2007.

Ngũgĩ wa Thiong'o. Devil on the Cross. Heinemann, 1987.

. Matigari. Trans. Wangũi wa Goro. Heinemann, 1987.

Petals of Blood. Heinemann, 1977.

Ngũgĩ wa Thiong’o \& Ngũgĩ wa Mĩriĩ. I Will Marry When I Want. Heinemann, 1982. 